\title{
Irritant-Induced Asthma and Reactive Airways Dysfunction Syndrome (RADS)
}

\section{Stuart M Brooks}

College of Medicine, University of South Florida, USA

Corresponding author: Stuart M Brooks,University of South Florida, 13201 Bruce B Downs Blvd, Tampa, FL 33612, USA, Tel: 813-928-8994/813-389-6000; Fax: 727-940-5566; E-mail: sbrooks@health.usf.edu

Rec date: Mar 01, 2014, Acc date: May 19, 2014, Pub date: May 22, 2014

Copyright:@ 2014 Brooks SM. This is an open-access article distributed under the terms of the Creative Commons Attribution License, which permits unrestricted use, distribution, and reproduction in any medium, provided the original author and source are credited.

\begin{abstract}
Irritant-induced asthma affects about one-fifth of workers with the diagnosis of 'occupational asthma'. There are believed to be two types of irritant-induced asthma. Single exposure-type of irritant-induced asthma occurs when a person inhales a very high concentration of an irritant gas, vapor or fume to manifest newly-developed asthma symptoms plus nonspecific airway hyperresponsiveness within 24-hours following the exposure. In contrast, repeated exposure irritant-induced asthma evolves when a purportedly genetically predisposed individual is repeatedly exposed to non-massive levels of an irritant gas, vapor or fume (or as a mixture) over a few days, weeks or months and eventually develops clinical asthma. The treatment of RADS is similar to the treatment afforded patients suffering from an acute inhalational injury. Aerosolized bronchodilators are essential for treating acute bronchoconstriction. Likely, oral corticosteroids are not effective. There is no human study showing efficacy of oral corticosteroids in the treatment of RADS. Inhaled steroids have been found effective in reducing airway hyperresponsiveness in a case considered to be RADS.
\end{abstract}

Keywords: Irritant-induced asthma; Reactive airways dysfunction syndrome; Non-allergic asthma

\section{Abbreviations:}

SENSOR: Sentinel Event Notification System for Occupational Risks; RADS: Reactive Airways Dysfunction Syndrome; RAD: Reactive Airways Disease; LICEDS: Low-Intensity Chronic Exposure Dysfunction Syndrome

\section{Introduction}

Irritant-induced asthma affects less than one-fifth of workers with the diagnosis of 'occupational asthma' [1-7]. Between 1993 to 2003, the Sentinel Event Notification System for Occupational Risks (SENSOR) collected data from four states (California, Massachusetts, Michigan, and New Jersey); 445 cases of Reactive Airways Dysfunction Syndrome (RADS) represents $9 \%$ of work-related asthma events [1]. Data published by SWORD (Surveillance of Work-Related and Occupational Respiratory Diseases) and OPRA (Occupational Physicians Reporting Activity) for the years, between 1992 and 2001, emphasizes that RADS comprises between $13.7 \%$ and $29 \%$ of incident work-related respiratory diseases depending on whether cases are reported by chest physicians or occupational physicians [8]. When comparing subjects with inhalation injuries to those with immunological occupational asthma, there is a predominance of men $[8,9]$ and smoking whereas atopy is less frequent.

Brooks et al. establish two models of irritant-induced asthma without latency [10]. Single exposure-type of irritant-induced asthma occurs when a person inhales a very high concentration of an irritant gas, vapour or fume to manifest newly-developed asthma symptoms plus nonspecific airway hyperresponsiveness within 24-hours following the exposure. In contrast, repeated exposure irritantinduced asthma evolves when a purportedly genetically predisposedindividualis repeatedly exposed to non-massive levels of an irritant gas, vapour or fume (or as a mixture) over a few days, weeks or months and eventually develops clinical asthma.

\section{Single Exposure Irritant-Induced Occupational Asthma}

Reactive Airways Dysfunction Syndrome (RADS) materializes as new-onset asthma without immunological sensitization within 24hours subsequent to a single, massive irritant gas, vapor or fume exposure [11-14]. Acute irritant-induced asthma and Reactive Airways Dysfunction Syndrome (RADS) are synonymous with single exposure irritant-induced occupational asthma. Usually, it is not possible to accurately gauge the precise concentration of the irritant exposure since almost all cases are accidental and occur without warning such as with an unanticipated explosion, accidental release of irritant(s) held under pressure, when there are activities taking place in a confined space having reduced exchange ventilation rate and/or reduced fresh air make-up and when there are emissions of airborne smoke and irritant gases accompanying a fire. Presumably in some poorly understood manner, a massive irritant exposure leads to persistent airway inflammation, altered airway remodeling, sustained airway hyperresponsiveness and asthmatic symptoms. It must be stressed that the reference of Reactive Airways Dysfunction Syndrome ('RADS') is not the same as the designation Reactive Airways Disease ('RAD') [15].

The latter is a code word for the general term of 'asthma' while RADS refers specifically to acute irritant-induced asthma caused by a high-level irritant exposure. Initially in the ensuing minutes after the exposure, the person experiencing RADS may note burning of their eyes, nose and throat due to the characteristic irritant nature of the exposure. Typically, symptoms begin with immediate-onset coughing. Both shortness of breath and chest discomfort can represent early complaints but wheezing usually takes longer to evolve. Within a few hours or possibly the next morning (and always within 24 hours after the accidental exposure) the affected individual seeks treatment in an 
emergency facility or a physician's office. In some cases respiratory symptoms associated with RADS are transient and resolve within 12 weeks or less [6]. In other cases of RADS, continuing asthma-type symptoms and nonspecific airway hyperresponsiveness persist for years following the inciting exposure [16]. The reason for the differences is unknown. One review of RADS cases reported a median duration of symptoms lasting 13 months [17]. The routine chest $\mathrm{x}$-ray is characteristically interpreted as being 'negative' without acute infiltrates or pleural changes. When performed, spirometric tests often display 'normal' or 'mild' airflow limitation with no 'significant' response to an inhaled bronchodilator.

Among the 10 subjects originally described by Brooks and coworkers, four had a reduced Tiffeneau index [18]. Persistent airflow limitation occurs only in a small percentage of persons with RADS. Bhérer and coworkers showed airflow obstruction in 31/51 (60\%) subjects assessed 18 to 24 months after inhalational accidents due to chlorine [19]. Some patients demonstrate a mixed spirometric pattern reflecting combined central and peripheral involvement [20,21].

The hallmark of RADS is persistent airway hyperresponsiveness as defined by a "positive' methacholine challenge test (e.g., PC20 for methacholine is $<8 \mathrm{mg} / \mathrm{ml}$ ). However, the level of bronchial hyperresponsiveness to methacholine tends to be mild or even borderline in some cases [22].It is important that other pulmonary conditions, that simulate RADS, are excluded including vocal cord dysfunction. Table 1 provides the diagnostic criteria for RADS.

1. Absence of pre-existing respiratory disorder, asthma symptomatology or a history of asthma in remission and exclusion of conditions that can simulate asthma

2. Onset of asthma after a single exposure or accident.

3. Exposure is to an irritant vapor, gas, fumes or smoke in very high concentrations.

4. Onset of asthma occurs within minutes to hours and always less than 24 hours after the exposure.

5. Finding of a positive methacholine challenge test $(<8 \mathrm{mg} / \mathrm{ml})$ following the exposure.

6. Possible airflow obstruction on pulmonary function testing.

7. Another pulmonary disorder to explain the symptoms and findings is excluded

Table 1: Diagnostic Criteria for RADS

\section{Repeated Exposure Irritant-Induced Occupational Asthma}

Repeated exposure-type of irritant-induced asthma has been classified under different names including: Repeated Exposure Irritant-Induced Asthma; 'Atypical RADS'; 'Low-Dose RADS'; LowIntensity Chronic Exposure Dysfunction Syndrome (LICEDS); 'NotSo-Sudden 'Irritant-Induced Asthma; and, 'Chronic Irritant-Induced Asthma [1,4,5,10,14,21,23-25]. In the repeated exposures-type of irritant-induced asthma, the clinical appearance of asthma takes longer to evolve and only after repeated irritant exposures. Table 2 proposes the diagnostic criteria necessary for establishing the diagnosis of repeated exposure irritant-induced asthma [26].

Numerous epidemiological surveys are conducted in workers repeatedly exposed to both low and high levels of chlorine, sulphur dioxide and/or ozone in pulp and paper mills [16,19,27-31]. Persistent asthmatic symptoms and presence of nonspecific bronchial hyperresponsiveness and/or variable airflow obstruction are reported among three pulp mill workers experiencing repeated chlorine "gassing" episodes occurring over several years [27]. Mild increases in bronchial responsiveness and other clinical associations appear during a two-year follow-up of Canadian workers undergoing repeated chlorine 'puff exposures [32]. Among 25 subjects, the onset of asthma symptoms takes longer to materialized following repeated irritant exposures taking place over days, weeks or months [10]. When analyzed, $88 \%$ of subjects were considered "atopic" and $40 \%$ developed new-onset asthma in the setting of underlying pre-existing asthma clinically quiescent for at least one year before the exposure [10].

1. There is no preceding latency but asthma symptoms commence during repeated intermittent or continuous inhalational exposures to non-massive, moderate, lower intensity but tolerable concentrations of an irritant vapor, gas, fumes or smoke.

2. Asthma symptoms start during the time repeated irritant exposures take place and not after cessation of exposure.

3. The duration of the repeated exposures is always more than 24 hours and typically does not last longer than 4 months of repeated exposures before asthma symptoms begin. Rarely does the irritant exposure last $\geq 1$-year before the initiation of asthma symptoms.

4. There is the absence of pre-existing asthma symptomatology for the previous 1-year or there may be a past history of childhood asthma that resolved or there was a past history of adult asthma in remission for at least 1year. There may have also been a diagnosis and/or treatment of bronchial asthma instituted by a previous physician.

5. Typical irritant-induced asthma symptoms include episodic coughing, wheezing and symptoms of "bronchial irritability", (i.e., acute respiratory complaints that follow exposures to various nonspecific irritants, physical factors and odors). There also may be intermittent chest tightness and nocturnal episodes of coughing, wheezing and breathlessness.

6. Spirometry may be normal, show airflow limitation and/or demonstrate a positive response $(\geq 12 \%)$ to an inhaled bronchodilator.

7. There is a positive methacholine challenge test $(<8 \mathrm{mg} / \mathrm{ml})$ that confirms the presence of nonspecific airway hyperresponsiveness.

8. There must be exclusion of alternative conditions that simulate asthma including vocal cord dysfunction. The possibility of occupational asthma caused by a workplace sensitizer is also eliminated.

Table 2: Diagnostic Criteria for Repeated Exposure Irritant-Induced Asthma

(Also, Not-So-Sudden Irritant-Induced Asthma, 'Low-Dose RADS' Or 'Low Intensity Chronic Exposure Dysfunction Syndrome, 'LICEDS')

\section{Etiological Agents}

Cases of inhalation accidents, reported to Surveillance Of WorkRelated and Occupational Respiratory Disease (SWORD) and the Open Public Records Act (OPRA) between 1992 and 2001,classified the offending agents into five categories. The most frequently reported agents were irritant gases $(42 \%)$ followed by solvent vapors $(18 \%)$, metallic fumes (11\%) acid mists (9\%) and other (18\%) [8]. The originally reported causative agents of RADS include: uranium hexafluoride gas, floor sealant, spray paint containing significant concentrations of ammonia, heated acid, 35-percent hydrazine, fumigating fog, metal coating remover, and smoke [12].

Table 3 lists reported causes of irritant-induced asthma and RADS. 


\begin{tabular}{|c|c|}
\hline Exposure & Agent or Process \\
\hline Acids & Glacial acetic, sulfuric, hydrochloric, hydrofluoric acid \\
\hline Alkali & $\begin{array}{l}\text { Ammonia, bleach, calcium oxide, sodium hydroxide, World } \\
\text { Trade Center dust, air bag emissions }\end{array}$ \\
\hline Gases & $\begin{array}{l}\text { Chlorine, sulfur dioxide, mustard, ozone, hydrogen sulfide, } \\
\text { phosgene, nitrogen dioxide; dinitrogen tetroxide }\end{array}$ \\
\hline Spraying & Spraying of paints and coatings \\
\hline Explosion & $\begin{array}{l}\text { Irritant gases, vapors and fume releases under pressure; } \\
\text { uranium hexafluoride; World Trade Center disaster }\end{array}$ \\
\hline Fire/pyrolysis & $\begin{array}{l}\text { Combustion and pyrolysis products of fires, burning paint } \\
\text { fumes, pyrolysis products of polyvinylchloride (PVC) meat } \\
\text { wrapping film; smoke inhalation, Chlorofluorocarbons } \\
\text { degradation, urea fumes }\end{array}$ \\
\hline Confined spaces & $\begin{array}{l}\text { Epichlorhydrin, acrolein, floor sealant, metal coating } \\
\text { remover, biocides, fumigating aerosol, cleaning aerosol } \\
\text { sprays, mixture of drain cleaning agents }\end{array}$ \\
\hline $\begin{array}{l}\text { Environment \& } \\
\text { Workplace }\end{array}$ & $\begin{array}{l}\text { SO2 gas in a pyrite dust explosion; locomotive and diesel } \\
\text { exhaust; Dunsmuir Metam Sodium Spill; aerosols of } \\
\text { metalworking fluids including aldehyde and formaldehyde; } \\
\text { aluminum smelter workers exposed to pot-room fumes; } \\
\text { metal processing plant and c chlorine gas exposures; } \\
\text { bleachery workers with ozone and chlorine dioxide/SO2 } \\
\text { gassings; chlorine gas "puffs" among pulp mill workers \& } \\
\text { chlorine gassing incidents; sodium persulfate; inorganic } \\
\text { salts used as oxidizing agents in hair bleaches \& hair- } \\
\text { coloring preparation; shoe and leather workers exposed to } \\
\text { the organic solvents ; workers exposed to SO2 from } \\
\text { apricot sulfurization tunnel construction workers, cleaning } \\
\text { and disinfecting workers in the food industry, chili pepper } \\
\text { pickers, dust exposure in Norwegian smelters; 2- } \\
\text { hydroxyethyl methacrylate and methyl methacrylate in } \\
\text { dentists; synthetic leather workers exposed to organic } \\
\text { solvents toluene, xylene and methyl ethyl ketone; } \\
\text { eucalyptus; fragranced aerosol products; gases from liquid } \\
\text { manure; steam system additive 2- } 2 \text {, symantaning } \\
\text { diethylaminoethanolamine; irritant gas containing } \\
\text { chromate at a chrome pellet manufacturing plant; } \\
\text { bromochlorodifluoromethane and bromotrifluoromethane. }\end{array}$ \\
\hline
\end{tabular}

Table 3: Causes of Irritant-Induced Asthma and RADS

\section{Cigarette Smoking and RADS}

Cigarette smoking is opined as a risk factor for occupational asthma even though its effect on the development of occupational asthma is still unclear [33]. As to date, there is no recognized association between cigarette smoking and non-allergic irritant-induced asthma or RADS [34,35]. Conceivably, a better distinction can be made after splitting allergic-occupational asthma from non-allergic occupational asthma/RADS. A proposed mechanism to explain the connection between cigarette smoking and allergic sensitization could be that inhalation of cigarette smoke injures the bronchial epithelium of certain workers leading to the widening of the tight junctions between epithelial cells; the change heightens bronchial epithelial permeability and permits greater penetration of antigen through the epithelial layer [36]. It is also possible that there may be the release of different mediators in smokers compared to non-smokers.

Perhaps in some cases, cigarette smoking predisposes individuals to allergic sensitization [37,38].Tobacco smoke provokes an increase in serum $\operatorname{IgE}$ and enhances respiratory sensitization to ovalbumin in animals studies [39]. A higher total IgE concentration has been noted in cigarette smokers' serum [40]. An association between atopy, cigarette smoking, and allergic sensitization to a workplace exposure is reported for workers exposed to green coffee beans, tetrachlorophthalic anhydride and platinum salts $[37,38,41]$. Both smoking and the intensity of platinum salts exposure were associated with development of platinum salt sensitivity among South African platinum refinery workers [37].Accordingly, evidence emerges of an increased risk of allergic occupational sensitization in cigarette smoking workers exposed to certain high and low molecular weight agents [33].

\section{Pathology of RADS and Irritant-Induced Asthma}

The pathological features of RADS showing mononuclear cell inflammation, denuded epithelium and edematous mucosa [12,42-45]. Additional pathological findings reveal mucosal squamous cell metaplasia, thickening of the basement membrane and reticular and collagen-associated bronchial wall fibrosis $[43,44,46]$. A subject suffering from RADS following a single exposure to a mixture containing an isocyanate disclosed mainly aT-lymphocytes inflammatory response [47]. Purportedly, a case of RADS in a worker exposed to chlorine gas showed asequence of pathological changes [22]. Serial bronchial biopsies acquired at 3 and 15 days and then 3 and 5 months after the inhalational accident demonstrated Initial bronchial mucosal denudation, sloughing of epithelial cells and infiltration of a submucosal fibrinohemorrhagic exudate. Subsequent changes unveiled subepithelial edema and cellular regeneration of the basal and parabasal cells; even later, there was deposition of collagen. In another human investigation studied approximately 11 years after the inhalational accident suggested the key cellular role of the eosinophil [48]. A rat model describedmaximalepithelial flattening and necrosis arisingbetween 1 and 3 days after a single high-level exposure to chlorine gas. Bronchoalveolar lavage documented neutrophilic inflammation [49]. With time and after further goblet cells and smooth muscle cells appeared, there was reduction in the amount of epithelial flattening and cellular necrosis. Some rats showed persistent epithelial aberrations [49].

\section{Possible Mechanisms Explaining Irritant-Induced Asthma and RADS}

\section{Geneticfactors}

Molecular variation in a gene sequencemightinflict greater host susceptibilityfor lung injury [50-62]. A mouse model of chlorineinduced pulmonary injury supports the hypothesis that some of the functional and pathological airways changes in asthma relate to induction of oxidative stress [63]. Inadequate antioxidant defense and genetic factors have been implicated in the pathogenesis of isocyanateinduced asthma $[62,64,65]$. Polymorphic variant in the class $\pi$ glutathione-S-transferase locus confers susceptibility to developing Toluene Di-Isocyanate (TDI) asthma; and, the homozygosity for the Val105-encoding alleles confers protection [66]. Achange in gene structure may causean inability to efficiently detoxify Reactive Oxygen Species (ROS) that serve as subcellular messengers for many genetic pathways $[57,67]$. The cellular damage perpetuated by a persistent oxidant stress couldoverwhelm the pulmonary antioxidant defenses leading to ensuing airway inflammation, airway hyperresponsiveness and other features of irritant-induced asthma [68]. Among lung antioxidants, glutathione is considered to be a potential susceptibility factor for asthma [59,66,69-71]. Theoretically, glutathione Stransferase influences how an individual handles an inflammatory- 
derived ROS burden. Intermediate metabolites can damage cells and generate oxidative stress, and therefore contribute to the pathogenesis of asthma. In some manner, the intermediate electrophilic metabolites arising in the first phase of detoxification, might not be metabolized and/or excreted by glutathione transferase enzymes in asthmatic patients.

\section{Ionic channels}

Irritant exposures may alter pulmonary ionic channels such as the transient receptor potential vanilloid-1 (TRPV1) and TRPA 1 [2,72-82]. (Normally, these channels are primed to recognize irritant chemical and to counter with appropriate neurogenic and biochemical rejoinders [Brooks SM, 2008 \#2677). When there is significant cellular damagefrom a high-level irritant exposure, cellsrelease inflammatory products such as bradykinin, ATP, prostaglandin E2, Nerve Growth Factor, proteases andserotonin that sustainand potentiate the responsiveness of TRPV1 and TRPA1receptors/channels [83-86]. TRPV1 and TRPA1 channels manifest much higher neuronal Ca2+ responsiveness to irritant chemicals, in such a sustained and potentiated state, and introduce changes leading to irritant-induced asthma. Previously unresponsive neuronal tissues can gainhigher sensitivity and display more prolonged neuronal signalling [87]. Neuropeptides released from activated nerve endings lead to localized neurogenic inflammation (see below). The finality of the various alterations leads to sustained airway inflammation, neural plasticity, airway remodeling, persistent airway hyperresponsiveness and clinical asthma symptoms.

\section{Tachykinins and Neurotrophins}

The release and subsequent actions of tachykinins and neurotrophins submit an another explanation for airway inflammation and hyperresponsiveness afterirritant-induced airway epithelial injury $[88,89]$. Neuropeptides released from nerve endings evoke neurogenic inflammation [72,90-96]. For example, Nerve Growth Factor (NGF), accumulating in inflamed tissue, can induce different cells to release pro-inflammatory mediators. In part, sustained neurogenic inflammation evokes a release of cytokines and pro-inflammatory molecules thatfunction in both an autocrine and paracrine manner to create a feedback mechanism causing more NGFrelease [97]. Under the influence of inflammation, nerves undergo remodeling (i.e. neural plasticity) [98]. Neural plasticity appearing in an inflamed airway may both increase synthesis of tachykinins and facilitate its release [98,99]. Neural plasticity induces nervoushyperactivity that translates as bronchial hyperresponsiveness [98].

\section{Airway smooth muscle}

Airway Smooth Muscle (ASM) cells regulate airway tone in asthma through the release and response to various cytokines, growth factors and mediators of airway inflammation [100,101]. Borger et al proposed that the pathogenesis of asthma could relate to an abnormal phenotype of airway smooth muscle where there is faster proliferation of ASM cells; the quickening might contribute to the increase in ASM mass found in patients with asthma [102]. Increases in ASM mass, epithelial goblet cell hyperplasia, bronchial epithelial abnormalities, lamina reticularis thickening, proliferation of airway blood vessels and nerves are key structural changes in the airways of asthmatics. Cultured ASM cells of patients with asthma produce less prostaglandin E2 but show greater number of E-prostanoid receptors on the cell membrane [102]. PGE2 is the major prostanoid produced by ASM cells and can lead to the inhibition of ASM cellular proliferation. Both PGE2 and PGF2 $\alpha$ directly activate lung C-fibers.

\section{Abnormal airway remodelling}

The initiation of an abnormal Epithelial-Mesenchymal Trophic Unit (EMTU) in response to an irritant may be because the bronchial epithelial cells of asthmatics are more responsive to environmental irritants [103].

\section{Subclinical asthma}

Severe early-onset asthma, appearing first during childhood, is associated with a strong allergic component, eosinophilic inflammation and diminished anti-inflammatory response to corticosteroid resistance. Adult-onset asthma without airway eosinophilia may signify a distinct clinical type of asthma [104]. Feasibly, the asymptomatic individual with roots of childhood asthma may have their asthma exacerbated or aggravated by accidental single or repeated irritant exposures $[10,105,106]$. The reason for this conclusion is because the type of asthma originating in infancy or childhood was believed to have an encouraging future prognosis. Presumably, many cases went into "remission" or displayed a reduction in asthma symptoms between the ages of 10 and 20 years [107]. It is now recognized that this assumption is not always correct. While the severity of asthma symptoms fluctuates with time, the inherited tendency towards respiratory symptoms never disappears; and,a majority of young adults who seem to be free of asthmatic symptoms do, in fact, have persistent asthma symptoms [108-111]. Even in the absence of current asthma symptoms, asymptomatic asthmatic subjects can still demonstratesubstantial air flow limitation and show increases in bronchial hyperresponsiveness [112-115].

\section{Asthma clinical phenotype}

Perhaps, repeated exposure-type irritant-induced asthma exemplifies a distinct asthma phenotype dependent on the type of airway cellular inflammation and the airway's unique response to environmental stimuli [116-118]. Bronchoscopic evaluation of the types of airways' cells has been utilized to investigate difficult-to-treat asthma and define asthma phenotypes [118-120].

\section{Prognosisof Irritant-Induced Asthma and RADS}

The long-term outcome of irritant-induced asthma was examined in a follow-up study of 35 subjects reassessed nearly 14 years after their inhalational accident [16]. The type of causal agent, the interval since the accident, and a visit to an emergency room or a hospitalization were not predictors of prognosis. In this investigation, asthma symptoms persisted in all subjects and more than two thirds required inhaled corticosteroids. Nearly $50 \%$ revealed bronchial obstruction and $75 \%$ showed bronchial hyperresponsiveness. One quarter of the sample of subjects manifested bronchial eosinophilic inflammation. Workers often reported impaired smell after the inhalational accidents. It seems that the long-term outcome of subjects with irritant-induced asthma is similar to subjects with allergic occupational asthma. As for allergic-type occupational asthma, approximately $25 \%$ of subjects show a disappearance of bronchial hyperresponsiveness two years after the inhalational accident with a plateau afterwards [121]. 


\section{Treatment of Irritant-Induced Asthma}

The treatment of RADS is similar to the treatment afforded patients suffering from an acute inhalational injury. Aerosolized bronchodilators are essential for treating bronchoconstriction (as measured by spirometry) or bronchospasm (as determined by auscultation finding of wheezing). The beneficial effect of parenteral steroids has been shown in an animal model of RADS in which dexamethasone was administered immediately before chlorine inhalation [49]. There are no human study showing efficacy of oral corticosteroids in the treatment of RADS cases; and, possibly oral steroids may not be effective. Inhaled steroids have been found effective in reducing airway hyperresponsiveness in a case considered to be RADS [22]. A substantial number of patients with RADS show biopsy findings of eosinophilic inflammation many years after the acute inhalational accident [16]. These findings are used as a justification for employing inhaled steroids to treat RADS.

\section{References}

1. Bernstein IL, Chan-Yeung M, Luc-Malo J, Bernstein DI (2006) Definition and classification of asthma in the workplace In: Bernstein IL, ChanYeung M, Malo JL, Bernstein DI, editors. Asthma in the workplace and related conditions (3 edn) New York, NY: Taylor and Francis Group: 1-8.

2. Brooks SM (2010) Occupational, environmental, and irritant induced cough. In: Ken W. Altman MD PhD and Richard S. Irwin MD GE, editor. Cough: An interdisciplinary problem OtolaryngolClin North Am: 85-96.

3. Chatkin JM, Tarlo SM, Liss G, Banks D, Broder I (1999) The outcome of asthma related to workplace irritant exposures: a comparison of irritantinduced asthma and irritant aggravation of asthma. Chest 116: 1780-1785.

4. Henneberger PK, Derk SJ, Davis L, Tumpowsky C, Reilly MJ, et al. (2003) Work-related reactive airways dysfunction syndrome cases from surveillance in selected US states. J Occup Environ Med 45: 360-368.

5. Malo JL, Lemière C, Gautrin D, Labrecque M (2004) Occupational asthma. CurrOpinPulm Med 10: 57-61.

6. Nemery B (1996) Late consequences of accidental exposure to inhaled irritants: Rads and the bhopal disaster. EurRespir J 8: 1973-1976.

7. Nemery B (2006) Inhalation injury, chemical. In: B. N, editor. Occupational diseases London: Elsevier Ltd: 208-216.

8. McDonald JC, Chen Y, Zekveld C, Cherry NM (2005) Incidence by occupation and industry of acute work related respiratory diseases in the UK, 1992-2001. Occup Environ Med 62: 836-842.

9. Tarlo SM, Broder I (1989) Irritant-induced occupational asthma. Chest 96: 297-300.

10. Brooks SM, Hammad Y, Richards I, Giovinco-Barbas J, Jenkins K (1998) The spectrum of irritant-induced asthma: sudden and not-so-sudden onset and the role of allergy. Chest 113: 42-49.

11. Bardana EJ Jr (1999) Reactive airways dysfunction syndrome (RADS): guidelines for diagnosis and treatment and insight into likely prognosis. Ann Allergy Asthma Immunol 83: 583-586.

12. Brooks SM, Weiss MA, Bernstein IL (1985) Reactive airways dysfunction syndrome (RADS). Persistent asthma syndrome after high level irritant exposures. Chest 88: 376-384.

13. Malo JL (1998) Irritant-induced asthma and reactive airways dysfunction syndrome. Can Respir J 5: 66-67.

14. Tarlo SM (2010) Irritant-induced asthma PCCSU 24 (Lesson 22): 1-6.

15. Fahy JV, O'Byrne PM (2001) "Reactive airways disease". A lazy term of uncertain meaning that should be abandoned. Am J RespirCrit Care Med 163: 822-823.

16. Malo JL, L'archevêque J, Castellanos L, Lavoie K, Ghezzo H, et al. (2009) Long-term outcomes of acute irritant-induced asthma. Am J RespirCrit Care Med 179: 923-928.
17. Shakeri MS, Dick FD, Ayres JG (2008) Which agents cause reactive airways dysfunction syndrome (RADS)? A systematic review. Occup Med (Lond) 58: 205-211.

18. Swanney MP, Ruppel G, Enright PL, Pedersen OF, Crapo RO, et al. (2008) Using the lower limit of normal for the FEV1/FVC ratio reduces the misclassification of airway obstruction. Thorax 63: 1046-1051.

19. Bherer L, Cushman R, CourteauJp, Quevillon M, Cote G, et al. (1994) Survey of construction workers repeatedly exposed to chlorine over a three to six month period in a pulpmill: II. Follow up of affected workers by questionnaire, spirometry, and assessment of bronchial responsiveness 18 to 24 months after exposure ended. Occup Environ Med 51: 225-228.

20. Charan NB, Myers CG, Lakshminarayan S, Spencer TM (1979) Pulmonary injuries associated with acute sulfur dioxide inhalation. Am Rev Respir Dis 119: 555-560.

21. Gilbert R, Auchincloss JH Jr (1989) Reactive airways dysfunction syndrome presenting as a reversible restrictive defect. Lung 167: 55-61.

22. Lemiere C, Malo JL, Boutet M (1997) Reactive airways dysfunction syndrome due to chlorine: Sequential bronchial biopsies and functional assessment. EurRespir J 10: 241-244.

23. Kipen HM, Blume R, Hutt D (1994) Asthma experience in an occupational and environmental medicine clinic. Low-dose reactive airways dysfunction syndrome. J Occup Med 36: 1133-1137.

24. Tabar AI, Alvarez MJ, Acero S, Olaguíbel JM, García BE, et al. (1998) Reactive airways dysfunction syndrome: two case reports. J InvestigAllergolClinImmunol 8: 119-122.

25. Tarlo SM, Balmes J, Balkissoon R, Beach J, Beckett W, et al. (2008). Diagnosis and management of work-related asthma. American college of chest physicians consensus statement. Chest 134: 1S-41S.

26. Brooks SM, Gautrin D, Malo JL (2013) Reactive airways dysfunction syndrome and irritant induced asthma. In: Bernstein IL, Chan Yeung M, Malo JL, DI B, editors. Asthma in the workplace: Marcel Dekker Taylor \& Francis Group partners.

27. Chang-Yeung M, Lam S, Kennedy SM, Frew AJ (1994) Persistent asthma after repeated exposure to high concentrations of gases in pulpmills. Am J RespirCrit Care Med 149: 1676-1680.

28. Gautrin D, Leroyer C, L'Archevêque J, Dufour JG, Girard D, et al. (1995) Cross-sectional assessment of workers with repeated exposure to chlorine over a three year period. EurRespir J 8: 2046-2054.

29. Henneberger PK, Olin AC, Andersson E, Hagberg S, Torén K (2005) The incidence of respiratory symptoms and diseases among pulp mill workers with peak exposures to ozone and other irritant gases. Chest 128: 3028-3037.

30. Olin AC, Granung G, Hagberg S, Adriansson M, Brisman J, et al. (2002) Respiratory health among bleachery workers exposed to ozone and chlorine dioxide. Scand J Work Environ Health 28: 117-123.

31. Olin AC, Andersson E, Andersson M, Granung G, Hagberg S, et al. (2004) Prevalence of asthma and exhaled nitric oxide are increased in bleachery workers exposed to ozone. EurRespir J 23: 87-92.

32. Gautrin D, Leroyer C, Infante-Rivard C, Ghezzo H, Dufour JG, et al. (1999) Longitudinal assessment of airway caliber and responsiveness in workers exposed to chlorine. Am J RespirCrit Care Med 160: 1232-1237.

33. Siracusa A, Marabini A, Folletti I, Moscato G (2006) Smoking and occupational asthma. ClinExp Allergy 36: 577-584.

34. Brooks SM (1998) Occupational and environmental asthma. In: Rom WN, editor. Environmental and occupational medicine. Philadelphia: Lippincott-Raven: 481-524.

35. Brooks SM (2007) Inhalation airway injury: A spectrum of changes. ClinPulm Med 14: 330-337.

36. Goldie RG, Pedersen KE (1995) Mechanisms of increased airway microvascular permeability: role in airway inflammation and obstruction. ClinExpPharmacolPhysiol 22: 387-396.

37. Calverley AE, Rees D, Dowdeswell RJ, Linnett PJ, Kielkowski D (1995) Platinum salt sensitivity in refinery workers: incidence and effects of smoking and exposure. Occup Environ Med 52: 661-666. 
38. Venables KM, Dally MB, Nunn AJ, Stevens JF, Stephens R, et al. (1989) Smoking and occupational allergy in workers in a platinum refinery. BMJ 299: 939-942.

39. Zetterström O, Nordvall SL, Björkstén B, Ahlstedt S, Stelander M (1985) Increased IgE antibody responses in rats exposed to tobacco smoke. J Allergy ClinImmunol 75: 594-598.

40. Burrows B, Halonen M, Barbee RA, Lebowitz MD (1981) The relationship of serum immunoglobulin E to cigarette smoking. Am Rev Respir Dis 124: 523-525.

41. Beckett WS (1994) The epidemiology of occupational asthma. EurRespir J 7: 161-164.

42. Bernstein IL, Bernstein DI (1989) Reactive airways dysfunction syndrome (RADS) after exposure to toxic ammonia fumes. J Allergy ClinImmunol 83: 173-179.

43. Deschamps D, Rosenberg N, Soler P, Maillard G, Fournier E, et al. (1992) Persistent asthma after accidental exposure to ethylene oxide. Br J Ind Med 49: 523-525.

44. Deschamps D, Soler P, Rosenberg N, Baud F, Gervais P (1994) Persistent asthma after inhalation of a mixture of sodium hypochlorite and hydrochloric acid. Chest 105: 1895-1896.

45. Lemière C, Chaboilliez S, Trudeau C, Taha R, Maghni K, et al. (2000) Characterization of airway inflammation after repeated exposures to occupational agents. J Allergy ClinImmunol 106: 1163-1170.

46. Gautrin D, Bernstein IL, Brooks SM, Henneberger P (2006) Reactive airways dysfunction syndrome, or irritant induced asthma. In: Bernstein IL, Chan Yeung M, Luc-Malo J, D. B, editors. Asthma in the workplace.

47. Lemiere C, Malo J-L, Boulet LP, Boutet M (1996) Reactive airways dysfunction syndrome induced by exposure to a mixture containing isocyanate: Functional and histopathologic behaviour. Allergy 51: 262-265.

48. Takeda N, Maghni K, Daigle S, L'Archevêque J, Castellanos L, et al. (2009) Long-term pathologic consequences of acute irritant-induced asthma. J Allergy ClinImmunol 124: 975-981.

49. Demnati R, Fraser R, Ghezzo H, Martin JG, Plaa G, et al. (1998) Timecourse of functional and pathological changes after a single high acute inhalation of chlorine in rats. EurRespir J 11: 922-928.

50. Bird A (2007) Perceptions of epigenetics. Nature 447: 396-398.

51. Duffy DL, Mitchell CA, Martin NG (1998) Genetic and environmental risk factors for asthma: a cotwin-control study. Am J RespirCrit Care Med 157: 840-845.

52. Leikauf GD, McDowell SA, Wesselkamper SC, Hardie WD, Leikauf JE, et al. (2002) Acute lung injury: functional genomics and genetic susceptibility. Chest 121: 70S-75S.

53. Adcock IM, Brown CR, Kwon O, Barnes PJ (1994) Oxidative stress induces NF kappa B DNA binding and inducible NOS mRNA in the human epithelial cell line A549. BiochemSoc Trans 22: 186S.

54. Glavan BJ, Holden TD, Goss CH, Black RA, Neff MJ, et al. (2011) Genetic variation in the FAS gene and associations with acute lung injury. Am J RespirCrit Care Med 183: 356-363.

55. Levitt JE, Matthay MA (2010) The utility of clinical predictors of acute lung injury: towards prevention and earlier recognition. Expert Rev Respir Med 4: 785-797.

56. Samet JM, Hatch GE, Horstman D, Steck-Scott S, Arab L, et al. (2001) Effect of antioxidant supplementation on ozone-induced lung injury in human subjects. Am J RespirCrit Care Med 164: 819-825.

57. Wesselkamper SC, Prows DR, Biswas P, Willeke K, Bingham E, et al. (2000) Genetic susceptibility to irritant-induced acute lung injury in mice. Am J Physiol Lung Cell MolPhysiol 279: L575-582.

58. Holroyd KJ, Eleff SM, Zhang LY, Jakab GJ, Kleeberger SR (1997) Genetic modeling of susceptibility to nitrogen dioxide-induced lung injury in mice. Am J Physiol 273: L595-602.

59. Piirla P, Wikman H, Luukkonen R, Kaaria K, Rosenberg C, et al. (2001) Glutathione s-transferase genotype and allergic reponses to diisiocyante exposure. Pharmacogenetics 11: 437-445.
60. Puthothu B1, Krueger M, Heinze J, Forster J, Heinzmann A (2006) Impact of IL8 and IL8-receptor alpha polymorphisms on the genetics of bronchial asthma and severe RSV infections. ClinMol Allergy 4: 2 .

61. Wilk JB, Shrine NRG, Loehr LR, Zhao JH, Manihaikul A, et al. (2012) Genome-wide association studies identify CHRNA5/3 and HTR4 in the development of air?ow obstruction. Am J RespirCrit Care Med 186: 622-632.

62. Wikman H, Piirilä P, Rosenberg C, Luukkonen R, Kääriä K, et al. (2002) $\mathrm{N}$-Acetyltransferase genotypes as modifiers of diisocyanate exposureassociated asthma risk. Pharmacogenetics 12: 227-233.

63. Martin JG, Campbell HR, Iijima H, Gautrin D, Malo JL, et al. (2003) Chlorine-induced injury to the airways in mice. Am J RespirCrit Care Med 168: 568-574.

64. Wisnewski AV, Redlich CA (2001) Recent developments in diisocyanate asthma. CurrOpin Allergy ClinImmunol 1: 169-175.

65. Yucesoy B, Johnson VJ, Lummus ZL, Kissling GE, Fluharty K, et al. (2012) Genetic variants in antioxidant genes are associated with diisocyanate-induced asthma. Toxicol Sci 129: 166-173.

66. Aynacioglu AS, Nacak M, Filiz A, Ekinci E, Roots I (2004) Protective role of glutathione S-transferase P1 (GSTP1) Val105Val genotype in patients with bronchial asthma. Br J ClinPharmacol 57: 213-217.

67. Allen RG, Tresini M (2000) Oxidative stress and gene regulation. Free RadicBiol Med 28: 463-499.

68. Kelly FJ (2003) Oxidative stress: its role in air pollution and adverse health effects. Occup Environ Med 60: 612-616.

69. Lee YL, Lin YC, Lee YC, Wang JY, Hsiue TR, et al. (2004) Glutathione Stransferase $\mathrm{P} 1$ gene polymorphism and air pollution as interactive risk factors for childhood asthma. ClinExp Allergy 34: 1707-1713.

70. Mapp CE, Fryer AA, De Marzo N, Pozzato V, Padoan M, et al. (2002) Glutathione S-transferase GSTP1 is a susceptibility gene for occupational asthma induced by isocyanates. J Allergy ClinImmunol 109: 867-872.

71. Tamer L, CalikoÄŸlu M, Ates NA, Yildirim H, Ercan B, et al. (2004) Glutathione-S-transferase gene polymorphisms (GSTT1, GSTM1, GSTP1) as increased risk factors for asthma. Respirology 9: 493-498.

72. Trevisani M, Siemens J, Materazzi S, Bautista DM, Nassini R, et al. (2007) 4-Hydroxynonenal, an endogenous aldehyde, causes pain and neurogenic inflammation through activation of the irritant receptor TRPA1. ProcNatlAcad Sci U S A 104: 13519-13524.

73. Bautista DM, Movahed P, Hinman A, Axelsson HE, Sterner O, et al (2005) Pungent products from garlic activate the sensory ion channel TRPA1. ProcNatlAcad Sci U S A 102: 12248-12252.

74. Nilius B, Voets T, Peters J (2005) TRP channels in disease. Sci STKE 2005: re8.

75. McNamara CR, Mandel-Brehm J, Bautista DM, Siemens J, Deranian KL, et al. (2007) TRPA1 mediates formalin-induced pain. ProcNatlAcad Sci U S A 104: 13525-13530.

76. Macpherson LJ, Dubin AE, Evans MJ, Marr F, Schultz PG, et al. (2007) Noxious compounds activate TRPA1 ion channels through covalent modification of cysteines. Nature 445: 541-545.

77. Huang CL (2004) The transient receptor potential superfamily of ion channels. J Am SocNephrol 15: 1690-1699.

78. Adcock JJ (2009) TRPV1 receptors in sensitisation of cough and pain reflexes. PulmPharmacolTher 22: 65-70.

79. Zhang G, Lin RL, Wiggers M, Snow DM, Lee LY (2008) Altered expression of TRPV1 and sensitivity to capsaicin in pulmonary myelinated afferents following chronic airway inflammation in the rat. J Physiol 586: 5771-5786.

80. Taylor-Clark TE, McAlexander MA, Nassenstein C, Sheardown SA, Wilson S, et al. (2008) Relative contributions of TRPA1 and TRPV1 channels in the activation of vagal bronchopulmonary C-fibres by the endogenous autacoid 4-oxononenal. J Physiol 586: 3447-3459.

81. Takemura M, Quarcoo D, Niimi A, Dinh QT, Geppetti P, et al. (2008) Is TRPV1 a useful target in respiratory diseases? PulmPharmacolTher 21: 833-839. 
82. Medvedeva YV, Kim MS, Usachev YM (2008) Mechanisms of prolonged presynaptic $\mathrm{Ca} 2+$ signaling and glutamate release induced by TRPV1 activation in rat sensory neurons. J Neurosci 28: 5295-5311.

83. Bengtson SH, Eddleston J, Mörgelin M, Zuraw BL, Herwald H (2008) Regulation of kinin $\mathrm{B}(2)$ receptors by bradykinin in human lung cells. BiolChem 389: 1435-1440.

84. Gatti R, Andre E, Amadesi S, Dinh TQ, Fischer A, et al. (2006) Proteaseactivated receptor- 2 activation exaggerates TRPV1-mediated cough in guinea pigs. J ApplPhysiol (1985) 101: 506-511.

85. Nakatsuka T, Gu JG (2006) P2X purinoceptors and sensory transmission. Pflugers Arch 452: 598-607.

86. Vaughan R, Szewczyk JM, Lanos M, DeSesa CR, Gianutsos G, et al. (2006) Adenosine sensory transduction pathways contribute to activation of the sensory irritation response to inspired irritant vapors. Toxicol Sci 93: 411-421.

87. Woolf CJ, Ma Q (2007) Nociceptors--noxious stimulus detectors. Neuron 55: 353-364.

88. Groneberg DA, Niimi A, Dinh QT, Cosio B, Hew M, et al. (2004) Increased expression of transient receptor potential vanilloid-1 in airway nerves of chronic cough. Am J RespirCrit Care Med 170: 1276-1280.

89. Piedimonte G (1995) Tachykinin peptides, receptors, and peptidases in airway disease. Exp Lung Res 21: 809-834.

90. Amadesi S, Nie J, Vergnolle N, Cottrell GS, Grady EF, et al. (2004) Protease-acivated receptor-2 sensitizes the capsaicin receptor transient receptor potential vanilloid receptor 1 to induce hyperalgesia. J Neurosci 24: $4300-4312$.

91. Watanabe N, Horie S, Michael GJ, Keir S, Spina D, et al. (2006) Immunohistochemical co-localization of transient receptor potential vanilloid (TRPV)1 and sensory neuropeptides in the guinea-pig respiratory system. Neuroscience 141: 1533-1554.

92. Groneberg DA, Quarcoo D, Frossard N, Fischer A (2004) Neurogenic mechanisms in bronchial inflammatory diseases. Allergy 59: 1139-1152.

93. Widdicombe JG (2003) Overview of neural pathways in allergy and asthma. PulmPharmacolTher 16: 23-30.

94. Shusterman D (1994) Neurogenic inflammation: additional points. Environ Health Perspect 102: 12.

95. Meggs WJ (1994) RADS and RUDS--the toxic induction of asthma and rhinitis. J ToxicolClinToxicol 32: 487-501.

96. Meggs WJ (1993) Neurogenic inflammation and sensitivity to environmental chemicals. Environ Health Perspect 101: 234-238.

97. OlgartHöglund C, Frossard N (2002) Nerve growth factor and asthma. PulmPharmacolTher 15: 51-60.

98. Jacoby DB (2003) Airway neural plasticity: the nerves they are a-changin'. Am J Respir Cell MolBiol 28: 138-141.

99. Quarcoo D, Schulte-Herbruggen O, Lommatzsch M, Schierhorn K, Hoyle GW, et al. (2004) Nerve growth factor induces increased airway inflammation via a neuropeptide-dependent mechanism in a transgenic animal model of allergic airway inflammation. Clinexp Allergy 34: 1146-1151.

100. Joubert P, Hamid Q (2005) Role of airway smooth muscle in airway remodeling. J Allergy ClinImmunol 116: 713-716.

101. Lazaar AL, Panettieri RA Jr (2005) Airway smooth muscle: a modulator of airway remodeling in asthma. J Allergy ClinImmunol 116: 488-495.

102. Borger P, Tamm M, Black JL, Roth M (2006) Asthma: is it due to an abnormal airway smooth muscle cell? Am J RespirCrit Care Med 174: 367-372.
103. Holgate ST, Holloway J, Wilson S, Bucchieri F, Puddicombe S, et al. (2004) Epithelial-mesenchymal communication in the pathogenesis of chronic asthma. Proc Am ThoracSoc 1: 93-98.

104. Wenzel S (2005) Severe asthma in adults. Am J RespirCrit Care Med 172: 149-160.

105. Bradding P, Green RH (2010) Subclinical phenotypes of asthma. CurrOpin Allergy ClinImmunol 10: 54-59.

106. Sessions CK (2009) Asthma, active component, U.S. Armed forces, 1999-2008. In: Center AFHS, editor. Medical Surveillance Monthly Report (MSMR)- A publication of the Armed Forces Health Surveillance Center. Silver Spring, MD Armed Forces Health Surveillance Center (AFHSC): 5-9.

107. Panhuysen CI, Vonk JM, Koëter GH, Schouten JP, van Altena R, et al. (1997) Adult patients may outgrow their asthma: a 25-year follow-up study. Am J RespirCrit Care Med 155: 1267-1272.

108. BARR LW, LOGAN GB (1964) PROGNOSIS OF CHILDREN HAVING ASTHMA. Pediatrics 34: 856-860.

109. Riiser A, Hovland V, Carlsen KH, Mowinckel P, LødrupCarlsen KC (2012) Does bronchial hyperresponsiveness in childhood predict active asthma in adolescence? Am J RespirCrit Care Med 186: 493-500.

110. Roorda RJ (1996) Prognostic factors for the outcome of childhood asthma in adolescence. Thorax 51 1: S7-12.

111. Sears MR (2012) Predicting new and persistent asthma. Am J RespirCrit Care Med 186: 469-470.

112. Boulet LP (2003) Asymptomatic airway hyperresponsiveness: a curiosity or an opportunity to prevent asthma? Am J RespirCrit Care Med 167: 371-378.

113. Cooper DM, Cutz E, Levison H (1977) Occult pulmonary abnormalities in asymptomatic asthmatic children. Chest 71: 361-365.

114. Ferguson AC (1988) Persisting airway obstruction in asymptomatic children with asthma with normal peak expiratory flow rates. J Allergy ClinImmunol 82: 19-22.

115. Friberg S, Bevegård S, Graff-Lonnevig V (1988) Asthma from childhood to adult age. A prospective study of twenty subjects with special reference to the clinical course and pulmonary function. ActaPaediatrScand 77: 424-431.

116. Haldar P, Pavord ID, Shaw DE, Berry MA, Thomas M, et al. (2008) Cluster analysis and clinical asthma phenotypes. Am J RespirCrit Care Med 178: 218-224.

117. O'Donnell RA, Frew AJ (2002) Is there more than one inflammatory phenotype in asthma? Thorax 57: 566-568.

118. Wenzel SE (2006) Asthma: defining of the persistent adult phenotypes. Lancet 368: 804-813.

119. Wenzel SE, Schwartz LB, Langmack EL, Halliday JL, Trudeau JB, et al. (1999) Evidence that severe asthma can be divided pathologically into two inflammatory subtypes with distinct physiologic and clinical characteristics. Am J RespirCrit Care Med 160: 1001-1008.

120. Good JT Jr, Kolakowski CA, Groshong SD, Murphy JR, Martin RJ (2012) Refractory asthma: importance of bronchoscopy to identify phenotypes and direct therapy. Chest 141: 599-606.

121. Malo JL, Cartier A, Boulet LP, Archeveque J, Saint-Denis F, et al. (1994) Bronchial hyperresponsiveness can improve while spirometry plateaus two to three years after repeated exposure to chlorine causing respiratory symptoms. Am J RespirCrit Care Med 150: 1142-1145. 